\title{
Legal classification of the armed conflict in Ukraine in light of international humanitarian law
}

\author{
AgNiesZKa SZPAK*
}

\begin{abstract}
The armed conflict in Ukraine shows how difficult it sometimes is to clearly identify the nature of armed conflict. This is connected primarily with the lack of the full range of information on facts - knowledge of which is essential for determining the degree of control by a third country (Russia) over non-State party to an armed conflict (Ukrainian separatists). It is especially difficult to make such an assessment while armed conflict continues and is undoubtedly easier when the judgment is made after the fact, when there is access to intelligence and testimony of witnesses.

This paper presents a factual section which then concentrates on the legal framework for armed conflicts in general and examines the types of armed conflicts and international humanitarian law applicable to them. The legal ramifications are followed by an analysis of the events in the Crimea and eastern Ukraine in order to apply the law to the facts. The author attempts to establish whether the situation in the Crimea and eastern Ukraine is an international or non-international armed conflict and what law is applicable.
\end{abstract}

Keywords: Armed conflict, international humanitarian law, occupation, Ukraine, Crimea

\section{INTRODUCTION}

There are two types of events that need to be examined in the Ukraine: The events in the Crimea from the beginning of 2014 and the events that has been taking place in eastern Ukraine starting from the second half of 2014.

In order to set the context, there now follows an overview of factual events. On 26 February 2014, pro-Russian forces started to take control of the Crimea. These actions involved soldiers in Russian uniforms with no national insignia as well as Ukrainian soldiers and armed hostilities were minimal. The annexation of the Crimea practically met with no armed resistance. On 6 March 2014 Crimean parliament announced its decision to secede from Ukraine and join the Russian Federation and at the same time it was decided that a referendum on the status of Crimea would be held. It was held on 16 March 2014 and ended with a result of $95.5 \%$ votes in favor of joining Russia with the turnout on the level of $83 \% .{ }^{1}$ On 17 April, the Russian President W. Putin confirmed the participation of Russian forces in the occupation of Crimea. ${ }^{2}$ The referendum was conducted in the shadow of military occupation so it is difficult to regard it as lawful and its results as reliable. ${ }^{3}$ For that reason, an argument of intervention by invitation cannot be considered legitimate, the request by the former Ukrainian President cannot be a valid consent. ${ }^{4}$ The international community refused to acknowledge the annexation of the Crimea by Russia as it constituted a breach of the fundamental principles of international law. The United Nations General

* Nicolas Copernicus University in Torun, Poland Faculty of Political Science and International Studies Department of International and European Law Ul. Batorego 39 L 87-100 Torun, Poland e-mail: aszpak@umk.pl link 2.

1 BBC News 'Crimea referendum: Voters back Russia union' (2014) link 1; Vidmar (2014),

2 Heinsch (2015) 328.

${ }^{3}$ Kirsch (2014) link 3.

4 Gillich (2015) 1209. 
Assembly in its resolution 68/262 of 2014 expressed its commitment to the territorial integrity of Ukraine within its internationally recognized borders and underscored the invalidity of the 2014 Crimean referendum. ${ }^{5}$

With regard to the eastern Ukraine, in March 2014 pro-Russian protesters seized the regional administration building in Donetsk and commenced military operations there. Hostilities between separatists and the army of Ukraine covered the entire region of Donbas, including the main cities of Donetsk and Lugansk. The self-proclaimed 'Donetsk People's Republic' and 'Lugansk People's Republic' were created and in May 2014 pro-Russian separatists transformed them into a confederation - the Federative Republic of New Russia. ${ }^{6}$ Armed groups that have taken over government buildings in Donetsk and Lugansk hoisted a Russian flag which caused Ukraine, the USA and many European countries to accuse Russia of organizing these activities.

The term 'little green men' was coined after the arrival in the Crimea of armed men wearing Russian uniforms and guns but with no national insignia. ${ }^{7}$ Media reports estimate that approximately 9000 Russians were currently fighting in the eastern Ukraine on the side of separatists. ${ }^{8}$ This raises the question of the degree of control of those actions by the Russian authorities. Are Russian soldiers (it is time to end the 'little green men' fiction) receiving orders from their superiors or fighting on their own? The Russian authorities claim that only volunteers from Russia and soldiers who took leave in their units are fighting in the eastern Ukraine. ${ }^{9}$ Establishing the facts is important because it affects the classification of armed conflict on the eastern Ukraine as only afterwards can they be subsumed into the applicable law.

Other forms of support rendered to separatists by Russia include providing weapons and heavy equipment and training separatists. Satellite images and reports provided by NATO indicate that Russian soldiers take direct part in hostilities in Ukraine. ${ }^{10}$

After stating the facts, this paper concentrates on the legal framework for armed conflicts and examines the types of armed conflicts and the applicable international humanitarian law. This analysis will be limited to international and non-international armed conflicts and the term 'hybrid warfare' will be excluded, with suitable justification, as this is not a legal term of art. Much attention will be devoted to international jurisprudence, especially of the International Criminal Tribunals for the Former Yugoslavia (ICTY) that

5 UN GA Res. 68/262 (2014) link 4.

${ }^{6}$ Heinsch (2015) 328-30.

7 Reeves, Wallace (2015) 367.

8 Bender (2015) link 5.

9 Heinsch (2015) 330. See also 'No Russian Military Forces in Ukraine, Russian Envoy Tells OSCE' (2014), link 7.

10 Heinsch (2015) 330. On the facts in Ukraine see also Reeves and Wallace (2015) 365-71; Bebler (2015) 35-54; Hughes (2014) 106-18. Direct participation in hostilities has been defined in the ICRC Interpretative Guidance on the Notion of Direct Participation in Hostilities under International Humanitarian Law of 2009. There was indications that such a participation consists of three cumulative elements ' 1 . the act must be likely to adversely affect the military operations or military capacity of a party to an armed conflict or, alternatively, to inflict death, injury, or destruction on persons or objects protected against direct attack (threshold of harm), and 2. there must be a direct causal link between the act and the harm likely to result either from that act, or from a coordinated military operation of which that act constitutes an integral part (direct causation), and 3. the act must be specifically designed to directly cause the required threshold of harm in support of a party to the conflict and to the detriment of another (belligerent nexus)' - Melzer (2009) 46 link 8. 
defined the notion of armed conflict and the threshold criteria for international humanitarian law's applicability. A few remarks will be devoted to the International Court of Justice's famous Nicaragua case of 1986 where the Court elaborated on the notion of effective control. Then the events in the Crimea and eastern Ukraine will be analysed in order to apply the law to the stated facts. It will be established whether the situation in the Crimea and eastern Ukraine is an international or non-international armed conflict and what law is applicable. This is the core research question of the article - what is the legal character of the armed conflict in Ukraine? The answer to this question determines the applicable law.

This paper uses content analysis of most of all relevant international legal jurisprudence, academic articles and books, international non-governmental organizations' reports, e.g., Amnesty International and Human Rights Watch, as well as media reports. This analysis will allow the drawing of specific and more general conclusions on the content of international humanitarian law and its applicability to the armed conflict in eastern Ukraine and the Crimea.

\section{LEGAL FRAMEWORK FOR ARMED CONFLICTS}

This section examines the types of armed conflict and applicable law. International humanitarian law of armed conflict applies to armed conflicts of international and noninternational character and thus it is advisable to define these concepts. Hague Regulations of 1899 and 1907 and the Geneva Conventions of 1929 refer to the traditional concept of war while the four Geneva Conventions of 1949 utilize the term 'armed conflict'.11 In accordance with Art. 2 (1) common to the four Geneva Conventions, international armed conflict takes place when military hostilities between two or more parties to the Convention occurs. The Convention applies 'to all cases of declared war or of any other armed conflict which may arise between two or more of the High Contracting Parties, even if the state of war is not recognized by one of them'. ${ }^{12}$ Therefore, the international armed conflict is synonymous with inter-state conflict. It is irrelevant whether war was declared as well as whether the state of war was recognized by either party. In order to determine whether the Convention is applicable, it is necessary for the facts to reach the level of the state of international armed conflict. ICRC Commentary explains that 'any difference arising between two States and leading to the intervention of members of the armed forces is an armed conflict within the meaning of Article 2' ${ }^{13}$ The Geneva Conventions do not put a very high threshold, virtual no barrier of intensity of an armed conflict to be able to classify as an international conflict. In fact, it is sufficient that armed forces are used between at least two States. To make the legal picture complete, Additional Protocol I expanded the

11 Convention (IV) respecting the Laws and Customs of War on Land and its annex: Regulations concerning the Laws and Customs of War on Land. The Hague (1907); Convention (I) for the Amelioration of the Condition of the Wounded and Sick in Armed Forces in the Field (1949), Convention (II) for the Amelioration of the Condition of Wounded, Sick and Shipwrecked Members of Armed Forces at Sea (1949), Convention (III) relative to the Treatment of Prisoners of War (1949), Convention (IV) relative to the Protection of Civilian Persons in Time of War (1949). On the concept of war/armed conflict in international law see: Greenwood (1987) 283-306; Greenwood (2003) 79193; Pejić (2007) 77-100.

12 For example: Convention (I) for the Amelioration of the Condition of the Wounded and Sick in Armed Forces in the Field (1949).

13 ICRC Commentary to Geneva Convention III, 23 link 9. 
definition of international armed conflict to include national liberation wars, i.e., 'armed conflicts in which peoples are fighting against colonial domination and alien occupation and against racist régimes in the exercise of their right of self-determination' (Art. 1 (4) and the Additional Protocol). ${ }^{14}$ However, this provision does not apply to the armed conflict in Ukraine as in the case of the eastern Ukraine as there is no war of self-determination being waged and the case of the Crimea constitutes occupation of the part of the State territory. In addition, the Geneva Conventions, or more broadly, international humanitarian law, also apply 'to all cases of partial or total occupation of the territory of a High Contracting Party, even if the said occupation meets with no armed resistance' [art. 2 (2) of the Geneva Conventions]. ${ }^{15}$

The definition of non-international armed conflict cannot be found in common Art. 3, which only states that it applies to armed conflicts not having an international character occurring in the territory of one of the Contracting Parties (i.e. States). This provision does not specify any conditions of its application beyond the general statement indicated above. Guidance might be found in the ICRC Commentary to the Geneva Conventions which contains authoritative interpretative suggestions for establishing the existence of a non-international armed conflict. Amongst the circumstances indicating the existence of a non-international armed conflict are the following:

(1) That the Party in revolt against the de jure Government possesses an organized military force; an authority responsible for its acts; acting within a determinate territory and having the means of respecting and ensuring respect for the Convention.

(2) That the legal Government is obliged to have recourse to the regular military forces against insurgents organized as military and in possession of a part of the national territory.

(3) (a) That the de jure Government has recognized the insurgents as belligerents; or (b) That it has claimed for itself the rights of a belligerent; or (c) That it has accorded the insurgents recognition as belligerents for the purposes only of the present Convention. (d) That the dispute has been admitted to the agenda of the Security Council or the General Assembly of the United Nations as being a threat to international peace, a breach of the peace, or an act of aggression.

(4) (a) That the insurgents have an organization purporting to have the characteristics of a State. (b) That the insurgent civil authority exercises de facto authority over the population within a determinate portion of the national territory. (c) That the armed forces act under the direction of an organized authority and are prepared to observe the ordinary laws of war. (d) That the insurgent civil authority agrees to be bound by the provisions of the Convention. ${ }^{16}$

These criteria are designed to help distinguish conflicts from ordinary acts of banditry or disorganized or short-term uprisings. Additional Protocol II applicable to noninternational armed conflicts formulate criteria for applicability definitely more difficult to meet. Additional Protocol II applies to conflicts

14 Protocol Additional to the Geneva Conventions of 12 August 1949, and relating to the Protection of Victims of International Armed Conflicts (1977); Emanuelli (2009) 107-09.

15 For example: Convention (I) for the Amelioration of the Condition of the Wounded and Sick in Armed Forces in the Field (1949).

16 ICRC Commentary to Geneva Convention III, 36, link 9. 
(...) which take place in the territory of a High Contracting Party between its armed forces and dissident armed forces or other organized armed groups which, under responsible command, exercise such control over a part of its territory as to enable them to carry out sustained and concerted military operations and to implement this Protocol (...). ${ }^{17}$

This definition includes armed conflicts of high intensity involving organized armed groups generally taking the form very similar to armed conflict of an international character. $^{18}$

Attempts at defining the term 'armed conflict' have also been undertaken in the international jurisprudence. First of all, one should note the decision of the Appeals Chamber of the International Criminal Tribunal for the Former Yugoslavia (ICTY) on the Defence Motion for Interlocutory Appeal on Jurisdiction, Prosecutor v. D. Tadić, Appeals Chamber, 1995. ICTY - when analyzing the existence of the state of armed conflict formulated a definition of armed conflict which has been repeated in virtually every subsequent judicial decision as well as by the scholars. The Appeals Chamber found that 'an armed conflict exists whenever there is a resort to armed force between States [an international armed conflict - A. Sz] or protracted armed violence between governmental authorities and organized armed groups or between such groups within a State [a noninternational armed conflict - A. Sz.]'. ${ }^{19}$ Furthermore, the Tadic Appeals Chamber held that

[i]nternational humanitarian law applies from the initiation of such armed conflicts and extends beyond the cessation of hostilities until a general conclusion of peace is reached; or, in the case of internal conflicts, a peaceful settlement is achieved. Until that moment, international humanitarian law continues to apply in the whole territory of the warring States or, in the case of internal conflicts, the whole territory under the control of a party, whether or not actual combat takes place there. ${ }^{20}$

The Tadic definition of armed conflict was subsequently adopted in the judgment of the International Criminal Court in the Lubanga case ${ }^{21}$ and in the judgment of the Special Tribunal for Sierra Leone in the Sesay, Kallon, Gbao case. ${ }^{22}$

17 Protocol Additional to the Geneva Conventions of 12 August 1949, and relating to the Protection of Victims of Non-International Armed Conflict (1977); Emanuelli (2009) 110-15.

18 On the definition of armed conflict construed on the basis of the ICTY jurisprudence see Stewart (2003) 313-50. See also Meron (1998) 236-42; Nier III (1991-1992) 303-31. See also the literature pointing to some factors that must be taken into consideration when establishing the character of the armed conflicts in the former Yugoslavia: Meron (1998) 214; Scharf, Epps (1996) 655-58; Alvarez (1996) 245-64; King, La Rosa (1997) 144-46; Aldrich (1996); Meron (1996), $238-49$.

19 Prosecutor v D. Tadić (Decision on the Defence Motion for Interlocutory Appeal on Jurisdiction) 70. On the definition of armed conflict construed on the basis of ICTY jurisprudence see: Stewart (2003) 313-50; Meron (1998) 236-42; Nier III (1991-1992) 303-31; Cullen (2010) 117-39.

${ }^{20}$ Prosecutor $v$ D. Tadic (Decision on the Defence Motion for Interlocutory Appeal on Jurisdiction) 70.

21 Prosecutor v T. Lubanga Dyilo (Judgment) (International Criminal Court), 506.

22 Prosecutor v I. Hassan Sesay, M. Kallon and A. Gbao (Judgment) (Special Court for Sierra Leone) 95. 
In the case of the Prosecutor v. Boskoski and Tarculovski, in its judgment of 10 July 2008, ICTY Trial Chamber has analyzed the state of non-international armed conflict. It adopted the definition of armed conflict from the Tadic case, then examined the individual elements, such as the intensity of the conflict and the degree of organization of the parties to the conflict. These elements are intended to distinguish the non-international armed conflict from acts of banditry, unorganized and short-lived insurrections or terrorist activities which are not subject to international humanitarian law. ${ }^{23}$

In Boskoski and Tarculovski case the ICTY Trial Chamber took into account various factors to assess the intensity of the non-international armed conflict. They included the seriousness of armed attacks; the rise in the intensity of the armed hostilities; their territorial spreading and long-term nature; the increase in the number of government forces and mobilization and distribution of weapons among both parties to the conflict; the interest of the conflict in the UN Security Council; the high number of victims; the type of weapons used; the extent of the damage; the occupation of territory; roadblocks and orders of truce, attempts by representatives of international organizations to implement and maintain a truce. ${ }^{24}$ The Trial Chamber considered it important whether actions are committed in isolation or as part of a long-term campaign including the military engagement of both sides. The intensity of the armed conflict is reflected in the duration of a long campaign including armed hostilities of both sides. It was clarified that it is not important whether such actions can be defined as terrorist. ${ }^{25}$

The element of prolonged armed violence in the definition of non-international armed conflict has not been the subject of an in-depth analysis in the case law of the ICTY. This element draws attention to the factor of time in the definition of armed conflict. ${ }^{26}$ The Trial Chamber in the Boskoski and Tarculovski case analyzed the impact of terrorist activities as a factor that could contribute to the determination of the existence of the non-international armed. Taking into account that terrorist actions cannot be placed outside of the scope of international humanitarian law, the Chamber stressed that the fact that acts of terrorism can be evidence of protracted armed violence is fully in line with the provisions of humanitarian law, which prohibits 'acts of terrorism' and 'acts or threats of violence the primary purpose of which is to spread terror among the civilian population' in both international and noninternational armed conflicts. It would be contradictory to say that international humanitarian law prohibits such acts but they do not fall within the scope of armed conflict. ${ }^{27}$ Thus, acts of terrorism can be regarded as indicative of the prolonged armed violence which, in turn, is treated as a criterion to prove the existence of an armed conflict.

The element of the degree of organization of the non-States armed group has not been clearly defined in the case law of the ICTY. However, one may point to a certain minimum degree of organization, which includes organization and hierarchy within such groups

23 Prosecutor v L. Boskoski, J. Tarculovski (Judgment) (International Criminal Tribunal for the former Yugoslavia) 175.

24 Prosecutor v L. Boskoski, J. Tarculovski (Judgment) (International Criminal Tribunal for the former Yugoslavia) 177.

25 Prosecutor v L. Boskoski, J. Tarculovski (Judgment) (International Criminal Tribunal for the former Yugoslavia) 185.

26 Prosecutor v L. Boskoski, J. Tarculovski (Judgment) (International Criminal Tribunal for the former Yugoslavia) 185-86.

27 Prosecutor v L. Boskoski, J. Tarculovski (Judgment) (International Criminal Tribunal for the former Yugoslavia) 187. 
similar to the regular army, structure, chain of command and a code of conduct which the non-State armed group applies. ${ }^{28}$ It should be emphasized that the Trial Chamber in the Boskoski and Tarculovski case did not consider violations of international humanitarian law as evidence of lack of organization within the non-State armed group fighting the government forces. It added that sometimes it is indeed a manifestation of poor discipline and, consequently, a smaller degree of organization, but this is not an automatic consequence. $^{29}$ It must be demonstrated in each individual case whether violations of international humanitarian law by the non-State armed group are a manifestation of lack of organization within its ranks.

The Trial Chamber in the above case noted that the above requirements are less stringent than those required for the application of Additional Protocol II, as the degree of organization within the meaning of common Art. 3 and in order to engage in 'long-term armed violence' is lower than for carrying out 'sustained and concerted military operations', which is required by the Additional Protocol II. ${ }^{30}$ The standard set out in the Tadic case and clarified in the judgment on Boskoski and Tarculovski judgment should be placed somewhere between the requirements of the common Art. 3 and the Additional Protocol II requirements.

\section{THE EFFECTIVE AND OVERALL CONTROL TESTS}

After outlining the legal regulations of the two types of armed conflicts, international and non-international ones, the issue of possible internationalization of the non-international armed conflict should be examined. An internal armed conflict may become international as a result of a third State military intervention on the side of the rebels or control of that third State over such non-governmental party to a conflict. ${ }^{31}$ In this last instance, two tests may be applicable, also to the armed conflict in Ukraine, a test of effective control and a test of overall control that were formulated in the international jurisprudence. The first test was coined by the International Court of Justice (ICJ) in its judgment on military and paramilitary activities in and against Nicaragua (1986). Nicaragua case concerned the responsibility of the State for violations of, among others, international humanitarian law. The ICJ stated that

United States participation, even if preponderant or decisive, in the financing, organizing, training, supplying and equipping of the contras, the selection of its military or paramilitary targets and the planning of the whole of its operation, is still insufficient in itself, on the basis of the evidence in the possession of the Court, for the purpose of attributing to the United States the acts committed by the contras in the course of their military or paramilitary operations in Nicaragua. All the forms of United States participation mentioned above and even the general control by the respondent State over a force with a high degree of dependency on it, would not in

28 Prosecutor v L. Boskoski, J. Tarculovski (Judgment) (International Criminal Tribunal for the former Yugoslavia) 194-95, 199-203.

29 Prosecutor v L. Boskoski, J. Tarculovski (Judgment) (International Criminal Tribunal for the former Yugoslavia) 205.

30 Prosecutor v L. Boskoski, J. Tarculovski (Judgment) (International Criminal Tribunal for the former Yugoslavia) 197.

31 Pejić (2007) 92. 
themselves mean, without further evidence, that the United States directed or enforced the perpetration of the acts contrary to human rights and humanitarian law alleged by the applicant State. Such acts could well be committed by members of the contras without the control of the United States. For this conduct to give rise to legal responsibility of the United States, it would in principle have to be proved that that State had effective control of the military or paramilitary operations in the course of which the alleged violations were committed (emphasis added).$^{32}$

In contrast, the overall control test was formulated in the 1999 ICTY Appeals Chamber judgment in the Tadić case. This case had a different dimension as it concerned individual responsibility (not that of the State) for violations of international humanitarian law. The ICTY had to determine the conditions that must be met for the internationalization of non-international armed conflict. The armed conflict is international in character, if it is waged between two or more States. The non-international armed conflict ongoing in the territory of one State can be transformed into an international armed conflict if another State takes direct military intervention in the conflict or if the non-State armed groups act on behalf of another State. ${ }^{33}$ The Appeals Chamber identified the legal criteria to be determined in an armed conflict of a non-international character that armed forces may be considered to be acting on behalf of a foreign State and therefore meet the criteria for internationalization of armed conflict. ${ }^{34}$ The Chamber noted that international humanitarian law does not contain any specific criteria to determine when a group of persons may be deemed to be under State control. It should, therefore, refer to international law in general. ${ }^{35}$

In the Nicaragua case, high degree of control was adopted. In that judgment the ICJ argued for the rule that the general situation of dependence and support is not a sufficient condition for attributing the behavior of a group to the State. It is often raised that the case before the ICJ concerned the international responsibility of the State and not, as in the case of Tadić, individual criminal responsibility. ${ }^{36}$ However, according to the Appeals Chamber, the case is not about two different regimes of responsibility. In the Tadic case, the preliminary question of the conditions the fulfillment of which is necessary for recognition in international law of entities as de facto organs of the State is important. In some cases, depending on the context of the case (State responsibility or individual criminal responsibility) fulfillment of these conditions, which means attribution of the actions of individuals who are de facto organs of the State to that State (actions involving violations of international law) will result in the international responsibility of the State and in others will give an armed conflict an international character. ${ }^{37}$

32 Military and Paramilitary Activities in and against Nicaragua (Nicaragua v. United States of America) I.C.J. reports 1986, 115.

33 Prosecutor v D. Tadić (Judgment) (International Criminal Tribunal for the former Yugoslavia) (1999) 84.

34 Prosecutor v D. Tadić (Judgment) (International Criminal Tribunal for the former Yugoslavia) (1999) 91.

35 Prosecutor v D. Tadić (Judgment) (International Criminal Tribunal for the former Yugoslavia) (1999) 98.

36 Prosecutor v D. Tadić (Judgment) (International Criminal Tribunal for the former Yugoslavia) (1999) 100-01.

37 Prosecutor v D. Tadić (Judgment) (International Criminal Tribunal for the former Yugoslavia) (1999) 104. 
International law makes the State responsible for inter alia acts committed in violation of the law by individuals being organs of that State (even if the organ acts ultra vires) and by the individuals that make up organized groups under the control of the State. This is the position of international law, regardless of whether the State issued specific instructions to such individuals. ${ }^{38}$ ICTY Appeals Chamber concluded that

international rules do not always require the same degree of control over armed groups or private individuals for the purpose of determining whether an individual not having the status of a State official under internal legislation can be regarded as a de facto organ of the State. The extent of the requisite State control varies. Where the question at issue is whether a single private individual or a group that is not militarily organised has acted as a de facto State organ when performing a specific act, it is necessary to ascertain whether specific instructions concerning the commission of that particular act had been issued by that State to the individual or group in question; alternatively, it must be established whether the unlawful act had been publicly endorsed or approved ex post facto by the State at issue. By contrast, control by a State over subordinate armed forces or militias or paramilitary units may be of an overall character (and must comprise more than the mere provision of financial assistance or military equipment or training). This requirement, however, does not go so far as to include the issuing of specific orders by the State, or its direction of each individual operation. Under international law it is by no means necessary that the controlling authorities should plan all the operations of the units dependent on them, choose their targets, or give specific instructions concerning the conduct of military operations and any alleged violations of international humanitarian law. The control required by international law may be deemed to exist when a State (or, in the context of an armed conflict, the Party to the conflict) has a role in organising, coordinating or planning the military actions of the military group, in addition to financing, training and equipping or providing operational support to that group. Acts performed by the group or members thereof may be regarded as acts of de facto State organs regardless of any specific instruction by the controlling State concerning the commission of each of those acts (emphasis added). ${ }^{39}$

Control required by international law may be sufficient when the State or in the case of armed conflict, the State-party to the conflict has a role in organizing, coordinating or planning military action. In conclusion, the Appeals Chamber of the ICTY found that the degree of control over organized subordinate armed groups, police or paramilitary troops required by international law for internationalization of non-international armed conflict can be described as overall control. This overall control requires more than just financing and equipping of such forces, and the State's participation in the planning and supervision of military operations is required. In contrast, international law does not require that such control includes the issuance of specific orders or instructions relating to military operations, regardless of whether such actions violate international humanitarian law. These instructions are required for the activities of individuals or unorganized groups - in the Tadić case ' $\mathrm{t}] \mathrm{he}$

38 Prosecutor $v$ D. Tadić (Judgment) (International Criminal Tribunal for the former Yugoslavia) (1999) 123.

39 Prosecutor v D. Tadić (Judgment) (International Criminal Tribunal for the former Yugoslavia) (1999) 137. 
ICTY applied the logic that if the conduct was attributable to a foreign state, then the armed conflict was to be regarded as an international one'. ${ }^{40}$

R. Heinsch noted that '[a]lthough still controversial in some ways, the overall control test nevertheless has become the accepted standard in international courts and tribunals when it comes to the classification of armed conflicts' ${ }^{41}$ The effective control test should be used at the same time for the purpose of holding a State responsible for internationally wrongful acts - in this case the degree of control has to be higher. This conclusion and differentiation may also be found in the attribution rule in Art. $8^{42}$ of the International Law Commission's Articles on State Responsibility (2001). ${ }^{43}$ Accordingly, a State is responsible for acts committed by its de facto organs only if they acted 'on instructions of, or under the direction or control of that State' and this formula seems to express the effective control test. ${ }^{44}$ Hence, those two tests should not be confused as their application serves different purposes. Naturally the argumentation a maiori ad minus applies here - if the effective control test is met, the internal conflict also becomes internationalized.

The International Court of Justice (ICJ), in its judgment on the Application of the Convention for the Prevention and Punishment of the Crime of Genocide (Bosnia and Herzegovina $v$ Serbia and Montenegro) of 2007 had the opportunity to comment on the relationship between the effective and overall control tests. In order to attribute Srebrenica's genocide to Serbia and establish liability, the ICJ considered it appropriate to apply the effective control test. The Court added that the overall control test was adopted by the ICTY in a different context - to determine the nature of the armed conflict for the purpose of individual criminal responsibility. The ICJ considered the overall control test to be equally important but simply adopted for other purposes and in another context. ${ }^{45}$ This statement may be regarded as another argument in favour of using the overall control test only to determine the character of the armed conflict.

\section{LEGAL EVALUATION OF THE EVENTS IN UKRAINE UNDER INTERNATIONAL HUMANITARIAN LAW}

A brief explanation will be given why the term 'hybrid warfare' has not been applied in the Ukrainian case. According to one definition, hybrid war is regarded as

[o]ne in which the distinctions between war and peace, combatants and non-combatants and aggression and defense blur, and territorial fronts give way to economic, industrial, technological, trade, media, energy supply, cyber-spatial and other overt and covert

40 Gillich (2015) 1205.

${ }^{41}$ Heinsch (2015) 344. T. Meron indicates that identification of a third State intervening in the conflict is necessary only for the establishment of the international character of the armed conflict see: Tyner (2006) 870 and 872. For some critical voices of the overall control test see: Klip, Sluiter (eds) (2001) 874. See also: La Haye (2008) 321; Felde and others (1997-1998) 1441-68; Scharf, Epps (1996) 635-64; von Sternberg (1996-1997) 351-84.

42 This rule states that 'The conduct of a person or group of persons shall be considered an act of a State under international law if the person or group of persons is in fact acting on the instructions of, or under the direction or control of, that State in carrying out the conduct' - Crawford (2002) 112.

43 Crawford (2002) 112.

44 Emanuelli (2009) 120.

45 ICJ, Application of the Convention for the Prevention and Punishment of the Crime of Genocide (Bosnia and Herzegovina v Serbia and Montenegro) of 2007 § 396-406. 
means of hostile engagement [...]. In contemporary hybrid wars, political, economic, informational, humanitarian and other non-military measures blend into, precede, or substitute traditional uses of force. They may be indistinguishable from hypercompetition, large-scale cyber-espionage and underhand encouragement and control of interstate shadow economy. ${ }^{46}$

Hybrid war is supposed to focus not exclusively on militarily defeating the enemy but also on gaining control and subjugation of the enemy through political, economic, informational, humanitarian and other measures. ${ }^{47}$ It may also be characterized by some asymmetry in the potential of the parties. Asymmetry is nothing new and has always been present in the capabilities and means that parties to armed conflict has had at their disposal. For example

state actors regularly use the indirect tactics of asymmetric warfare by blurring the line between combatant and civilian, conducting cyber-attacks and lethally targeting individual actors in order to gain a strategic advantage over their non-state adversaries. Similarly, non-state armed groups and insurgencies do not hesitate to use devices of conventional armed warfare, including traditional weaponry, in conflicts with state actors. $^{48}$

Shane R. Reeves and David Wallace describe the whole conflict in Ukraine as hybrid: '[w]ith an amalgamation of international and non-international characteristics, the entirety of the Ukraine conflict is perhaps best described as a 'hybrid war.' A hybrid war can refer to those conflicts that are a combination of unconventional and conventional tactics'. ${ }^{49}$ Among such tactics sometimes are enumerated cyber-attacks, ${ }^{50}$ espionage, hostile corporate takeovers, or wintertime gas-cuts. ${ }^{51}$ It is highly doubtful that all of them may be deemed acts of warfare. There have been statements on the uniqueness of the Ukrainian armed conflict but the term 'hybrid warfare' is not a legal term but a political description used mainly by political scientists. International humanitarian law envisages only international and non-international armed conflicts and the armed conflict in the eastern Ukraine must be classified as one of them. Tertium non datur. When determining the nature of the armed

46 Korhonen (2015) 457-58. See also: 'Ukrainian elder statesman: How Russian hybrid war is changing the world order' (2017), link 10.

47 Korhonen (2015) 459.

48 Reeves, Barnsby (2013), link 11. On the NATO website one may find such a statement: 'There is no discussion that adversaries, past and present, have developed creative uses of the 'fullspectrum' of warfare, including the use of regular and irregular tactics across all dimensions of war. Altogether this may well form a hybrid set of threats and strategy, but it is not clear why the term 'hybrid' should be used, beside its mere descriptive value. In practice, any threat can be hybrid as long as it is not limited to a single form and dimension of warfare. When any threat or use of force is defined as hybrid, the term loses its value and causes confusion instead of clarifying the 'reality' of modern warfare' - 'Hybrid war - does it even exist?' (2015), link 14.

49 Reeves, Wallace (2015) 364 link 14.

50 For more details on cyber-attacks meeting the thresholds of the use of force and the acts of warfare see Tallinn Manual 2.0 on the International Law Applicable to Cyber Operations (2017), link 15; Tallinn Manual on the International Law Applicable to Cyber Operations (2013), link 16.

51 Korhonen (2015) 460. On hybrid war in Ukraine see also: Hajduk, Stępniewski (2016) $37-52$. 
conflict in Ukraine, current international humanitarian law is capable of meeting such challenges as in the Ukrainian case without the need of inventing new terms that have no place in international law. Very often such terms are the consequences of the emergence of new technologies, e.g., gunpowder, military aircraft and modern-day drones. These terms may help to illustratively describe the features of an armed conflict, but only in political and military terms (including the use of new technologies) while, at the legal level, the facts have to be classified either as international or non-international armed conflict. ${ }^{52}$ The weakness of international humanitarian law, as of the whole body of international law, is its lack of implementation which is mostly due to the lack of political will to respect it. The questions emerges should States demand the change of law instead of respecting the law as it currently stands? Should State officials and sometimes also legal scholars accuse international humanitarian law of being insufficient or ineffectual without giving it a chance of fulfilling its goals when respected? Questions also arise when the armed conflict in Ukraine is termed a hybrid war, allegedly something new, and are new regulations need as the current ones insufficient? The answer to all these questions is no.

\section{THE CONFLICT IN CRIMEA}

In the Crimea situation, international humanitarian law is certainly applicable as there is clearly an occupation and consequently the law applicable to international armed conflicts applies here. In accordance with Art. 2 (2) common to the four Geneva Conventions, '[ $t$ ]he Convention shall also apply to all cases of partial or total occupation of the territory of a High Contracting Party, even if the said occupation meets with no armed resistance'. ${ }^{53}$ Thus, despite the absence of armed resistance on the part of Ukraine, international humanitarian law applicable to international armed conflicts is applicable in this context, because of the state of occupation. ${ }^{54}$ In such a case, the already mentioned 'little green men' qualify as combatants and prisoners of war after their capture protected by the Third Geneva Convention. Photographs and videos show that armed men looking like Russian soldiers appeared in Crimea. They used the same weapons as the Russian army; their trucks had Russian license plates and they spoke Russian. At the beginning of these activities, W. Putin

52 I also do not agree with the claims about 'the failure of international law - particularly the Law of Armed Conflict - to evolve with the hybridization of war. [...] To preempt the possibility of undermining efforts to humanize warfare, the international community must recognize that questions concerning the effectiveness and practicality of the Law of Armed Conflict are increasing as the hybridization of warfare becomes the new norm. Ignoring this trend, and believing that current legal conditions are sufficient, simply expedites the increasingly ineffectual regulation of contemporary armed conflicts and continues to undermine confidence in the Law of Armed Conflict. Instead, international efforts must be made to push the Law of Armed Conflict into the hybrid warfare age. Whether through treaties or legally obligated customs, the international community must update the Law of Armed Conflict to address the various questions created by hybrid warfare while simultaneously reemphasizing that the comprehensive humanitarian protections afforded under the laws of war remain sacrosanct' - Reeves, Barnsby (2013), link 11. The authors do not give any arguments justifying their far reaching position.

53 For example: Convention (I) for the Amelioration of the Condition of the Wounded and Sick in Armed Forces in the Field (1949).

${ }^{54}$ For more details on the subject of occupation see Ferraro (2012) 133-63; Blank (2014), link 6; Jorritsma (2014), link 12. See also the ICJ advisory opinion on the Legal Consequences of the Construction of a Wall in the Occupied Palestinian Territory, 2004, § 92-95. 
argued that these were members of the self-defense groups who organized themselves locally and allegedly bought their uniforms and equipment in the store. ${ }^{55}$ However, with time, the Russian president officially admitted that they were Russian soldiers ${ }^{56}$ and some of those unmarked soldiers admitted to Western journalists that they were Russians. ${ }^{57}$ G. Hughes also argues that the Russian occupying forces 'consisted either of personnel from the Black Sea Fleet (BSF) based in Crimea or troops sent from the Russian Federation'. ${ }^{58}$ Putin's admission proves that the events in Crimea should be classified as occupation within the meaning of Art. 2 of the Geneva Conventions and all the international humanitarian law applicable in international armed conflicts is applicable to the Crimea's occupation.

The situation is much more complicated in the case of eastern Ukraine as Russia, even if there were any doubts as to the classification of Russia's actions as aggression, undoubtedly violated the prohibition of threat and use of force expressed in art. 2 (4) of the UN Charter. In any case, these actions have violated the territorial integrity of Ukraine and this principle is one of the pillars of contemporary international law and of the international security. It is also worth adding that, according to Article 41 (2) of the UN International Law Commission's Articles on the State Responsibility for Internationally Wrongful Acts, no State shall recognize it as a legal situation created by a serious violations of its ius cogens obligations. ${ }^{59}$ The prohibition on the threat and use of force is such an obligation.

\section{THE CONFLICT IN EASTERN UKRAINE}

The ICRC statement of 23 July 2014 states that the armed conflict in eastern Ukraine is a non-international one ${ }^{60}-$ a view that is shared by Human Rights Watch ${ }^{61}-$, whereas Amnesty International regards the conflict as international armed conflict. ${ }^{62}$ Human Rights Watch added however, that non-international armed conflict may be transformed into an international one, if it is shown that the separatists were acting under the overall control of Russia. ${ }^{63}$ There is also a possibility of a parallel existence of an international and noninternational armed conflict: International between Ukraine and Russia in the case of Crimea and non-international between Ukraine and pro-Russian separatists. The wars in the former Yugoslavia clearly fit within this framework. ${ }^{64}$ The current dominant view, when dealing with such a complicated legal scenario, is to split up the different conflicts into separate armed confrontations, each one of them amounting either to an international armed conflict or to a non-international armed conflict. ${ }^{65}$ The status of the parties is decisive.

The armed conflict in eastern Ukraine can be considered as non-international armed conflict as it meets the criteria of the common Art. 3 as the conditions are not particularly

55 Shevchenko (2014), link 17.

56 Heinsch (2015) 353. See also Hughes (2014) 106.

57 Gillich (2015) 1195, 1206.

58 Hughes (2014) 106.

59 Articles on the Responsibility of States for Internationally Wrongful Acts (2001) link 19.

60 'Ukraine: ICRC calls on all sides to respect international humanitarian law (2014) link 20.

61 'Eastern Ukraine: Questions and Answers about the Laws of War' (2014) link 21.

62 'Ukraine: Mounting evidence of war crimes and Russian involvement' (2014) link 22.

63 Eastern Ukraine: Questions and Answers about the Laws of War' (2014) link 21.

64 Greenwood (1996) 269-75.

65 Vité (2015) link 18. 
difficult to meet. It is sufficient that an armed conflict breaks out in the territory of one of the State Parties. Separatists are sufficiently well organized and the conflict has reached an appropriate degree of intensity to qualify as non-international armed conflict within the meaning of common Art. 3. On the one side there is the Ukrainian army and on the other a well-organized armed group. The prolonged duration of hostilities; the high number of victims (over 6000 people ${ }^{66}$ ); and the use of heavy military equipment show a sufficient length and intensity of armed conflict, allowing its classification as non-international armed conflict within the meaning of common Art. 3, and within the meaning of the Tadic decision. In addition, the separatists are well organized, and have a hierarchical structure which consists of rank-and-file fighters and commanders issuing orders. Separatists also control part of the territory of Ukraine and conduct sustained and concerted military operations, hence the armed conflict in eastern Ukraine also qualifies as non-international armed conflict within the meaning of Additional Protocol II (Russia and Ukraine are party ${ }^{67}$ ). ${ }^{68}$ Shane R. Reeves and David Wallace also state that the armed conflict in eastern Ukraine is non-international in character. In their view,

Russia is, undoubtedly, involved in the ongoing Ukraine civil war. Though they consistently deny these accusations, there is overwhelming evidence showing the Russians actively equipping, training and even fighting alongside the separatists in eastern Ukraine. Yet it is difficult to determine the full extent and scope of their control of the separatists, as the Russian-backed rebels are seemingly independent actors. Without more evidence to clarify the Russian-separatist relationship, it is not known whether Russia is exercising a sufficiently high degree of control over the separatists to internationalize the well-established non-international armed conflict. Given this challenge and because of the overwhelming evidence supporting the existence of a non-international armed conflict, this article considers the situation in eastern Ukraine to qualify as the latter. ${ }^{69}$

Is there evidence to support the thesis of the internationalization of the armed conflict on the eastern Ukraine? In order to confirm the thesis it would be necessary to answer the following questions: Was there a direct intervention by Russia in military operations? If not, what degree of control by Russia over the separatist forces is necessary for the internationalization of the armed conflict?

Starting with the second question, the overall control test is regarded correct and applicable in this case study of the armed conflict in the eastern Ukraine. Has the overall control test been met in the case of armed conflict in the eastern Ukraine? Mere equipping (supplying weapons and heavy equipment) and financing Ukrainian separatists by Russia does not suffice, as already mentioned. It is necessary to also participate in planning and coordinating military activities of the separatists. There are some signs that Russia is actually doing the last element but there is a lack of complete certainty. Other facts that are relevant for assessing the fulfillment of the overall control test including statement by W. Putin that if he wanted he could conquer Kiev in two weeks (which is significant,

66 Report on the human rights situation in Ukraine (2015) link 23.

67 The list of States-parties to Additional Protocol II: https://www.icrc.org/applic/ihl/ihl.nsf/ States.xsp?xp_viewStates $=$ XPages_NORMStatesParties\&xp_treatySelected $=475$, link 13.

68 In this way also Heinsch (2015) 356.

${ }^{69}$ Reeves, Wallace (2015) 381-82 link 11. 
especially in the context of the occupation of the Crimea); the fact that W. Putin had the 'last word' on the terms of ceasefire agreement during talks held in Mińsk, which indicates to close cooperation between Russia and the separatists; ${ }^{70}$ an already mentioned seizure of the regional administration building in Donetsk by pro-Russian protesters in March 2014 and then proclamation of 'Donetsk People's Republic' and 'Lugansk People's Republic' in May 2014, by the pro-Russian separatists who later on transformed them into a confederation - the Federative Republic of New Russia - armed groups that have taken over government buildings in Donetsk and Lugansk hoisted a Russian flag. ${ }^{71}$

In addition to the overall control test, which as mentioned should be considered appropriate in this case, the direct participation of Russian troops ('little green men') on the side of separatists should be mentioned. The question arises whose authority were those soldiers fighting under? Russia or their own? Can such actions be considered as the direct intervention of Russia in the armed conflict? I. Nuzov and A. Quintin indicate that '[i]f even one Russian soldier is fighting against the Ukrainian army, Common Article 2 applies ${ }^{72}$ so the conflict is international in character. The answer to this question is extremely difficult, primarily because, as stated, Russia denied that 'little green men' were its soldiers. ${ }^{73}$ Removal of national insignia was supposed to introduce confusion and slow down defensive reaction on the part of Ukraine. Russia should not benefit from these actions and should not be rewarded with the recognition of the absence of any direct part in hostilities and classification of the armed conflict as non-international one. Despite the fact that Russia and its armed forces supported pro-Russian separatists, the commentators indicate that it is not entirely clear if Russian soldiers are fighting in Ukraine against the Ukrainian army. The situation is extremely interesting and at the same time highly confusing, as the engagement of Russian soldiers allows the conclusion that the armed conflict is international in nature, but to reach such a conclusion one must first determine the status of these soldiers ('little green men'). Evidence that the participation of the Russians in the armed conflict in eastern Ukraine is shown by the capture of Russian paratroopers from the 76th Airborne Division in August 2014. ${ }^{74}$ NATO also stated that in August 2014 more than 1,000 Russian soldiers took part in the armed conflict in Donbas. There are also many reports of Russian soldiers being killed in Ukraine. In addition, Russian troops were shelling the Ukrainian units from abroad (close to the border). Moreover, currently approximately 9000 Russian soldiers are directly participating in armed hostilities in eastern Ukraine. In July 2014, Ukraine accused Russia of having shot down a Ukrainian military aircraft. All these factors combined, assuming that all is true, point towards direct Russian involvement in eastern Ukraine in support of the rebels since July 2014. Hence, an international armed conflict. Such a conclusion does not rule out the possibility of a parallel non-international armed conflicts between the rebels and the government of Ukraine. ${ }^{75}$ Importantly, it does not matter that Russia denies its direct involvement because according to Art. 2 of the Geneva Conventions state of war exists regardless of whether it has been recognized by any of the parties. ${ }^{76}$

70 Heinsch (2015) 358.

71 Heinsch (2015) 328-30.

72 Nuzov, Quintin (2015) link 24.

73 Balzer (2015) 83; Korhonen (2015) 452; Gillich (2015) 1203-07, 1210-13.

74 Balzer (2015) 83.

75 International armed conflict in Ukraine (2017) link 25.

76 Heinsch (2015) 357. 


\section{CONCLUDING REMARKS}

The armed conflict in Ukraine shows how difficult it is to clearly identify the nature of armed conflict. This is connected primarily to the lack of a full range of information on facts, knowledge of which is essential for determining for example the degree of control by a third country (Russia) over non-State party to an armed conflict (Ukrainian separatists). It is especially difficult to make such an assessment whilst the armed conflict continues. Undoubtedly, it is easier when the judgment is made after the fact, when there is access to intelligence and testimony of witnesses. ${ }^{77}$ However, taking into account all the circumstances mentioned, it is clear that the armed conflict in eastern Ukraine has an international character ${ }^{78}$ and Russian soldiers called 'little green men', separatists and Ukrainian soldiers have the right to combatant status with all the consequences.

Events in the Crimea are an occupation, and consequently international humanitarian law applicable to international armed conflicts is pertinent. The armed conflict in eastern Ukraine is at the least non-international armed conflict to which common Article 3 and Additional Protocol II as well as the relevant norms of customary international law are applicable. However, one can defend the thesis that the conflict has been internationalized due to the participation in it by Russian soldiers. ${ }^{79}$ It seems that the nature of armed conflict should be regarded as an international one, despite some doubts, and thus greater protection should be accorded to individuals directly participating in armed hostilities and to those individuals that ceased such participation. The possibility of parallel international and noninternational armed conflicts should not be excluded.

Unfortunately, three years later the international community is still facing the armed conflict in eastern Ukraine and the Crimea is still under the Russian occupation. The events in Ukraine, classified as international armed conflict, still pose a threat to international security and debates as to the character of the armed conflict are still being conducted. This paper has attempted to at least clarify some doubts concerning the legal characterization of the armed conflict in Ukraine. In the end, it is also worth emphasizing that despite all the difficulties in asserting the legal status of the armed conflict in Ukraine, some of them deliberately caused by Russia, international humanitarian law of armed conflict is highly capable of meeting such challenges - its provisions are sufficient for the task of the legal classification of the armed conflict in Ukraine.

\section{REFERENCES}

\section{Legal sources}

Convention (IV) respecting the Laws and Customs of War on Land and its annex: Regulations concerning the Laws and Customs of War on Land. The Hague, signed 18 October 1907, International Peace Conference, The Hague, Official Record (entered into force 26 January 1910), <https://www.icrc.org/applic/ihl/ihl.nsf/vwTreatiesByDate.xsp>.

Convention (I) for the Amelioration of the Condition of the Wounded and Sick in Armed Forces in the Field signed 12 August 1949, Final Record of the Diplomatic Conference of Geneva of 1949, Vol. I, Federal Political Department, Bern (entered into force 21 October 1950), <https://www.icrc. org/applic/ihl/ihl.nsf/vwTreatiesByDate.xsp>.

77 Heinsch (2015) 359.

78 Contrary view was expressed by: Quenivet (2014) link 26.

79 Reeves, Wallace (2015) 364 link 11. 
Convention (II) for the Amelioration of the Condition of Wounded, Sick and Shipwrecked Members of Armed Forces at Sea, signed 12 August 1949, Final Record of the Diplomatic Conference of Geneva of 1949, Vol. I, Federal Political Department, Bern (entered into force 21 October 1950), $<$ https://www.icrc.org/applic/ihl/ihl.nsf/vwTreatiesByDate.xsp>.

Convention (III) relative to the Treatment of Prisoners of War, signed 12 August 1949, Final Record of the Diplomatic Conference of Geneva of 1949, Vol. I, Federal Political Department, Bern (entered into force 21 October 1950), <https://www.icrc.org/applic/ihl/ihl.nsf/vwTreatiesByDate. xsp>.

Convention (IV) relative to the Protection of Civilian Persons in Time of War, signed 12 August 1949, Final Record of the Diplomatic Conference of Geneva of 1949, Vol. I, Federal Political Department, Bern (entered 21 October 1950), <https:/www.icrc.org/applic/ihl/ihl.nsf/ vwTreatiesByDate.xsp>.

Protocol Additional to the Geneva Conventions of 12 August 1949 and relating to the Protection of Victims of International Armed Conflicts signed 8 June 1977, Official Records of the Diplomatic Conference on the Reaffirmation and Development of International Humanitarian Law applicable in Armed Conflicts, Bern, Federal Department of Foreign Affairs, 1978 (entered into force 7 December 1978).

Protocol Additional to the Geneva Conventions of 12 August 1949 and relating to the Protection of Victims of Non-International Armed Conflict signed 8 June 1977, Official Records of the Diplomatic Conference on the Reaffirmation and Development of International Humanitarian Law applicable in Armed Conflicts, Bern, Federal Department of Foreign Affairs, 1978 (entered into force 7 December 1978).

\section{Jurisprudence}

Application of the Convention for the Prevention and Punishment of the Crime of Genocide (Bosnia and Herzegovina $v$ Serbia and Montenegro), I.C.J. Reports 2007.

Legal Consequences of the Construction of a Wall in the Occupied Palestinian Territory, I.C.J. Reports, 2004.

Prosecutor v D. Tadić (Decision on the Defence Motion for Interlocutory Appeal on Jurisdiction) (International Criminal Tribunal for the former Yugoslavia, Appeals Chamber, Case No IT-94-1, 2 October 1995).

Prosecutor v T. Lubanga Dyilo (Judgment) (International Criminal Court, Trial Chamber I, Case No ICC-01/04-01/06, 14 March 2012).

Prosecutor v I. Hassan Sesay, M. Kallon and A. Gbao (Judgment) (Special Court for Sierra Leone, Trial Chamber I, Case No SCSL-04-15-T-1234, 2 March 2009).

Prosecutor v L. Boskoski, J. Tarculovski (Judgment) (International Criminal Tribunal for the former Yugoslavia, Trial Chamber II, Case No IT-04-82-T, 10 July 2008).

Military and Paramilitary Activities in and against Nicaragua (Nicaragua v. United States of America) (Judgment), I.C.J. Reports 1986.

Prosecutor v D. Tadić (Judgment) (International Criminal Tribunal for the former Yugoslavia, Appeals Chamber, Case No IT-94-1-A, 15 July 1999).

\section{Literature}

Aldrich, George H., 'Jurisdiction of the International Criminal Tribunal for the Former Yugoslavia', (1996) 1 American Journal of International Law 64-69.

Alvarez, Jose E., 'Nuremberg Revisited: The Tadic Case' (1996) 7 European Journal of International Law 245-64.

Balzer, Harley, 'The Ukraine Invasion and Public Opinion' (2015) 16 Georgetown Journal of International Affairs 79-93.

Bebler, Anton, 'Crimea and the Russian-Ukrainian Conflict' (2015) 1 (15) Romanian Journal of European Affairs 35-54.

Crawford, James, The International Law Commission's Articles on State Responsibility. Introduction, Text and Commentaries (Cambridge University Press 2002). 
Cullen, Anthony, The Concept of Non-International Armed Conflict in International Humanitarian Law (Cambridge University Press 2010).

Emanuelli, Claude, International Humanitarian Law (Éditions Yvon Blais 2009).

Felde, Kitty and others, 'The Prosecutor v. Dusko Tadic'(1997-1998) 13 American University International Law Review 1441-68.

Ferraro, Tristan, 'Determining the beginning and end of an occupation under international humanitarian law' (2012) 885 (94) International Review of the Red Cross 133-63.

Gillich, Ines, 'Illegally Evading Attribution? Russia's Use of Unmarked Troops in Crimea and International Humanitarian Law' (2015) 48 Vanderbilt Journal of Transnational Law 1191-223.

Greenwood, Christopher, 'International Humanitarian Law and the Tadic Case' (1996) 7 European Journal of International Law 265-83.

Greenwood, Christopher, 'The Concept of War In Modern International Law' (1987) 2 (36) The International and Comparative Law Quarterly 283-306.

Greenwood, Christopher, 'The Law of War (International Humanitarian Law)' in Evans Malcolm D. (ed), International Law (Oxford University Press 2003) 789-821.

Hajduk, Jurij and Stępniewski, Tomasz, 'Russia's Hybrid War with Ukraine: Determinants, Instruments, Accomplishments and Challenges' (2016) 2 Studia Europejskie 37-52.

Haye (la), Eve, War Crimes in Internal Armed Conflicts (Cambridge University Press 2008).

Heinsch R, 'Conflict Classification In Ukraine: The Return of the "Proxy War"?' (2015) 91 International Law Studies 323-60.

Hughes, Geraint, 'Ukraine: Europe's New Proxy War?' (2014) 1 Fletcher Security Review 105-18.

King, Faiza Patel and La Rosa, Anne-Marie, 'International Criminal Tribunal for the Former Yugoslavia: Current Survey. The Jurisprudence of the Yugoslavia Tribunal' (1994-1996) (1997) 8 European Journal of International Law 123-79.

Klip, André, Sluiter, Göran (eds), Annotated Leading Cases of International Criminal Tribunals. Volume II. The International Criminal Tribunal Rwanda 1994-1999 (Intersentia 2001).

Korhonen, Outi, 'Deconstructing the Conflict in Ukraine: The Relevance of International Law to Hybrid States and Wars' (2015) 16 German Law Journal 452-78.

Meron, Theodor, 'Classification of Armed Conflict in the Former Yugoslavia: Nicaragua's Fallout' (1998) 2 American Journal of International Law 236-42.

Meron, Theodor, War Crimes Law Comes of Age. Essays (Oxford University Press 1998).

Nier III, Charles Lewis, 'The Yugoslavian Civil War: An Analysis of the Applicability of the Laws of War Governing Non-International Armed Conflicts in the Modern World', (1991-1992) 10 Dickinson Journal of International Law 303-31.

Pejić, Jelena, 'Status of Armed Conflicts' in Wilmshurst, Elisabeth, Breau, Susan (eds), Perspectives on the ICRC Study on Customary International Humanitarian Law (Cambridge University Press 2007) 77-100.

Reeves, Shane R. and Wallace David, 'The Combatant Status of the 'Little Green Men' and Other Participants in the Ukraine Conflict' (2015) 91 International Law Studies 361-401.

Scharf Michael, Epps Valerie, 'The International Trial of the Century? A "Cross-Fire" Exchange on the First Case Before the Yugoslavia War Crimes Tribunal' (1996) 29 Cornell International Law Journal 635-63.

Stewart, James G., 'Towards a single definition of armed conflict in international humanitarian law: A critique of internationalized armed conflict' (2003) 850 International Review of the Red Cross $313-50$.

Tyner, Davis B., 'Internationalization of War Crimes Prosecutions: Correcting the International Criminal Tribunal for the Former Yugoslavia's Folly in Tadic' (2006) 18 Florida Journal of International Law 843-86.

Von Sternberg and Mark R., 'Yugoslavian War Crimes and the Search for a New Humanitarian Order: The Case of Dusko Tadic' (1997) 12 Journal of Civil Rights and Economic Development 351-84.

\section{Links}

1. BBC News, 'Crimea referendum: Voters back Russia union' (2014) <http://www.bbc.com/news/ world-europe-26606097> accessed 13 June 2017. 
2. Vidmar, Jure, 'Crimea's Referendum and Secession: Why it Resembles Northern Cyprus More than Kosovo' (2014) <http://www.ejiltalk.org/crimeas-referendum-and-secession-why-itresembles-northern-cyprus-more-than-kosovo/> accessed 13 June 2017.

3. Kirsch, Nico, 'Crimea and the Limits of International Law' <http://www.ejiltalk.org/crimea-andthe-limits-of-international-law/> accessed 13 June 2017.

4. United Nations General Assembly Resolution 68/262 (March 27, 2014) <http://research.un.org/ en/docs/ga/quick/regular/68> accessed 13 June 2017.

5. Bender, Jeremy, 'Former NATO commander: A new Russian offensive in eastern Ukraine is "imminent" (2015) Business Insider <http://www.businessinsider.com/new-russian-offensive-inukraine-is-imminent-2015-4> accessed 13 June 2017.

6. Blank, Laurie R., 'Ukraine's Crisis Part 2: LOAC's Threshold for International Armed Conflict' (2014) Harvard Law School, National Security Journal, <http://harvardnsj.org/2014/05/ukrainescrisis-part-2-loacs-threshold-for-international-armed-conflict/> accessed 13 June 2017).

7. 'No Russian Military Forces in Ukraine, Russian Envoy Tells OSCE' (2014) Sputnik News $<$ http://sputniknews.com/world/20140828/192427054/No-Russian-Military-Forces-in-UkraineRussian-Envoy-Tells-SCE.html\#ixzz3t2dytfgT> accessed 13 June 2017.

8. Melzer, Nils, 'Interpretative Guidance on the Notion of Direct Participation in Hostilities under International Humanitarian Law' (2009) < https://www.icrc.org/eng/assets/files/other/icrc-0020990.pdf> accessed 13 June 2017.

9. ICRC Commentary to Geneva Convention III, $<\mathrm{https} / /$ www.icrc.org/applic/ihl/ihl.nsf/Comment. $\mathrm{xsp}$ ?action=openDocument \&documentId=07B4DAD7719E37E4C12563CD00424D17> accessed 13 June 1017.

10. 'Ukrainian elder statesman: How Russian hybrid war is changing the world order' $(2017)<\mathrm{http}: / /$ foreignpolicy.com/2017/03/21/ukrainian-elder-statesman-how-russian-hybrid-war-is-changingthe-world-order/> accessed 16 June 2017.

11. Reeves Shane, Barnsby, Rob, 'The New Griffin of International Law: Hybrid Armed Conflicts' (2013) Harvard IR <http://hir.harvard.edu/article/?a=3045> accessed 13 June 2017.

12. Jorritsma, Remy, 'Ukraine Insta-Symposium: Certain (Para)Military Activities in the Crimea: Legal Consequences for the Application of International Humanitarian Law' (2014) <http:// opiniojuris.org/2014/03/09/ukraine-insta-symposium-certain-para-military-activities-crimealegal-consequences-application-international-humanitarian-law/> accessed 13 June 2017.

13. List of States-parties to Additional Protocol II: <https://www.icrc.org/applic/ihl/ihl.nsf/States. xsp?xp_viewStates $=$ XPages_NORMStatesParties\&xp_treatySelected $=475>$ accessed 13 June 2017.

14. 'Hybrid war - does it even exist?' (2015) <http://www.nato.int/docu/review/2015/Also-in-2015/ hybrid-modern-future-warfare-russia-ukraine/EN/> accessed 16 June 2017.

15. Tallinn Manual on the International Law Applicable to Cyber Operations (2013), <https://www. peacepalacelibrary.nl/ebooks/files/356296245.pdf> accessed 13 June 2017.

16. Tallinn Manual 2.0 on the International Law Applicable to Cyber Operations $(2017)<\mathrm{https} / /$ ccdcoe.org/tallinn-manual.html> accessed 13 June 2017.

17. Shevchenko, Vitaly, “Little green men' or 'Russian invaders'?' (2014) BBC News <http://www. bbc.com/news/world-europe-26532154> accessed 16 June 2017.

18. Vité, Sylvain, Co-existing international and non-international armed conflicts in one country (2015) < http://www.iihl.org/wp-content/uploads/2015/11/Vit\%C3\%A9.pdf > accessed 16 June 2017.

19. Articles on State Responsibility, UN International Law Commission (2001) $<$ http://legal.un.org/ ilc/texts/instruments/english/draft articles/9 6 2001.pdf $>$ accessed 13 June 2017.

20. 'Ukraine: ICRC calls on all sides to respect international humanitarian law, 23-07-2014 News Release 14/125, (2014) ICRC < https://www.icrc.org/eng/resources/documents/newsrelease/2014/07-23-ukraine-kiev-call-respect-ihl-repatriate-bodies-malaysian-airlines.htm> accessed 13 June 2017.

21. 'Eastern Ukraine: Questions and Answers about the Laws of War' (2014) Human Rights Watch $<$ https://www.hrw.org/news/2014/09/11/eastern-ukraine-questions-and-answers-about-laws-war> accessed 13 June 2017. 
22. 'Ukraine: Mounting evidence of war crimes and Russian involvement' (2014) Amnesty International <https://www.amnesty.org/en/latest/news/2014/09/ukraine-mounting-evidence-warcrimes-and-russian-involvement/> accessed 13 June 2017.

23. 'Report on the human rights situation in Ukraine, 1 December 2014 to 15 February 2015' (2015) ReliefWeb $<$ http://reliefweb.int/report/ukraine/report-human-rights-situation-ukraine-1-december2014-15-february-2015> accessed 13 June 2017.

24. Nuzov, Ilya, Quintin, Anne, 'The Case of Russia's Detention of Ukrainian Military Pilot Savchenko under IHL' (2015) EJIL Talk! <http://www.ejiltalk.org/the-case-of-russias-detentionof-ukrainian-military-pilot-savchenko-under-ihl/> accessed 13 June 2017.

25. International armed conflict in Ukraine (2017) <http://www.rulac.org/browse/conflicts/ international-armed-conflict-in-ukraine\#collapse2accord $>$ accessed 16 June 2017.

26. Quenivet, Noelle, 'Trying to Classify the Conflict in Eastern Ukraine....' (2014) IntLawGrrls $<$ http://ilg2.org/2014/08/28/trying-to-classify-the-conflict-in-eastern-ukraine/> accessed 13 June 2017. 